\title{
Chapter 1 \\ Integrated Strategies \\ for the Management of Wadi Flash \\ Floods in the Middle East and North \\ Africa (MENA) Arid Zones: The ISFF \\ Project
}

\author{
Sameh A. Kantoush, Mohamed Saber, Mohammed Abdel-Fattah, \\ and Tetsuya Sumi
}

\begin{abstract}
Sustainable management of wadi flash flood (WFF) risks is desperately needed to secure development in wadi systems. Due to rapid flow generation with sudden high flood peaks, spatiotemporal variability of rainfall occurrence, and poorly sited rapid development, most Middle East and North Africa (MENA) region have no comprehensive proper protection from WFFs. In arid regions, single mitigation measures, including storage dams, recharge dams, artificial lakes and embankments, are implemented, although soft mitigation measures are not dominant, such as early warning systems. The single management strategy under climate change impacts is not adequate to reduce flash flood risks; an integrated strategy is required. The objective of the international symposium on flash floods (ISFF) project has been to develop scientific understanding of WFFs in wadi systems; monitor, model, and mitigate; issue warnings; and plan urban development by discussing and networking the strategies in the MENA region. To achieve this goal, the project defines priorities for future research challenges and potential projects for WFFs. This chapter provides a state-of-the-art scientific basis in terms of integrated flash flood management. Further, priorities are defined for the main research gaps, and the emerging research methodologies can contribute to guide the management of WFFs in such regions.
\end{abstract}

Keywords Wadi flash floods ISFF - Flood risk management $\cdot$ MENA region

\footnotetext{
S. A. Kantoush $(\bowtie) \cdot$ M. Saber · T. Sumi

Disaster Prevention Research Institute, Kyoto University, Goka-sho, Uji City, Kyoto 611-0011, Japan

e-mail: kantoush.samehahmed.2n@kyoto-u.ac.jp

M. Abdel-Fattah

Civil Engineering and Quantity Surveying Department, Military Technological College, P.O.

Box: 262, P.C: 111, Muscat, Oman

(C) The Author(s) 2022

T. Sumi et al. (eds.), Wadi Flash Floods, Natural Disaster Science and Mitigation

Engineering: DPRI Reports, https://doi.org/10.1007/978-981-16-2904-4_1
} 


\subsection{Introduction}

'Wadi' is an Arabic word that is commonly used to refer to dry stream channels and ephemeral streams or valleys typically in arid zones, such as in the Middle East and North Africa (MENA) countries (Jackson and Bates 1997; Sen 2008). In the past (before the year 2003, usually in late October or November), rainfall in the wadis can be described as episodic, varying widely on spatial and temporal scales, with many years receiving no precipitation at all. Recently, in the last 10 years, wadi flash floods (WFFs) in arid regions have become catastrophic and more frequent due to climate change impacts. In direct response to intense and usually sudden rains, WFFs can produce enough runoff such that wadis flow for some distance within the basin, but the flow often does not reach the coast because of high transmission losses, as documented by El Bastawesy et al. (2009), who analyzed pre- and post-flood remotely sensed data. Therefore, water harvesting of flash flood water can be a significant approach to mitigate some potential wadis.

Floods are natural disasters worldwide; however, their adverse impact is superior in developing countries (Alcántara-Ayala 2002). It was recently reported by the United Nations Office for Disaster Risk Reduction (UNISDR) that Arabian countries were affected by many disasters (approximately 270) over the last 30 years, resulting in over 150,000 deaths and influencing approximately 10 million people (Guha-Sapir et al. 2016). Recently, WFFs have been extreme and frequent in most of the MENA arid zone, resulting in substantial economic and property losses. For instance, flash floods struck Egypt, Jordan, and Saudi Arabia 39 times from 19002016, causing 1,508 casualties and significant damages exceeding 1.8 billion USD (De Vries et al. 2018). For instance, October 2016 flash floods left 26 dead people and tens of millions of USD in damages in Ras Gharib City (Abdel-Fattah et al. 2017). Due to extreme precipitation in Sudan during a 6-h period on 7 August 2013, the Humanitarian Aid Commission (HAC) estimated that 499,900 people countrywide had been impacted and more than 85,385 houses were destroyed in the affected states, with Khartoum State experiencing the worst effects (IFRC 2013). Flash floods in Oman are often caused by more severe phenomena, which include tropical cyclones that bring massive devastation to infrastructure and the loss of human life. Oman was also hit by an extreme cyclone in July 2007 that killed 54 people, and property damage was assessed at 3.9 billion USD (Al Khatry and Helmi 2008; Al Barwani 2015). In October 2018, the increased frequency of extreme rainfall events associated with various flash floods triggered widespread destruction in most of the MENA region, including Jordan, Kuwait, Qatar, Saudi Arabia, the UAE, Morocco, Tunisia, Algeria, Mauritania, Sudan and Oman. Because previous experience of such disasters in arid regions is limited, proper planning and management are now required. Events such as those in Egypt (2010), Oman (2007), Yemen (2008), Jordan (2012), and Bahrain (2008) ensure that WFFs remain the leading meteorological disaster causing death and property damage. These floods destroy the main infrastructure, such as buildings, villages, agricultural lands, roads, power towers, and pipelines, and they injure and kill humans and 
animals (Murata et al. 2015; Abdel-Fattah et al. 2018). In 2018, wadi flooding trapped tourists and forced 4,000 tourists to evacuate to safe places within $1 \mathrm{~h}$ before the peak flood reached the historic site of Petra, Jordan (Guardian 2018). Sirens blared minutes before extreme flash flooding after heavy rainfall approached Petra (historical city, dating back to 9,000 B.C.). The last deadly flash flood hit Petra in 1963, when 22 French tourists and a local guide were killed by flash floods (Laure Van Ruymbeke 2018).

Monitoring, modelling and early warning of WFFs are difficult, especially in ungauged wadis. Furthermore, the lack of a complete data archive of pre- and post-WFF events across the MENA region obstructs efforts to mitigate the flooding risk (Viglione and Rogger 2014; Saber and Habib 2015). Most of the published studies regarding WFFs have focused on the geology, geomorphology, and hydrogeology of wadi systems (Moneim 2005; Elewa and Qaddah 2011; Abdelkareem and El-Baz 2015). The other flash-flood-related features of wadi systems, such as integrated management, hydrological modelling, and risk assessment, have not been sufficiently addressed. Unfortunately, modelling the response of wadis to rainfall is challenging due to the lack of data and to special characteristics of wadis; consequently, developing powerful hydrological models is difficult (Wheater et al. 2007). Different rainfall modelling tools and methodologies have been widely used, but most of them were originally established for humid environments; nevertheless, arid and semi-arid regions facing severe water resources scarcity and flash flood threats have received little attention. The lack of high-quality observations is hindering the development in arid regions (Pilgrim et al. 1988). Precipitation events are spatiotemporally irregular, highly variable and localized. Flow measurements are lacking or uncertain. Moreover, some of the developed hydrological models that were constructed for humid conditions cannot be easily adapted to arid environmental conditions (Cools et al. 2012). Generally, in humid environments, during the dry seasons, flow discharge increases downstream and groundwater contributes to river systems, whereas in arid environments, the opposite is valid, the surface flow is reduced because the groundwater table is usually depressed (Sen 2008). For these reasons, the hydrological processes of arid lands differ from those of humid lands and present particular challenges. Developing hydrological models and methodologies is urgently needed in arid and semi-arid regions. According to many previous studies, nonrioting and measuring of flow is mostly problematic in arid regions for numerous reasons (Rodier and Roche 1978; Kilpatrick and Cobb 1985; Pilgrim et al. 1988; Lange et al. 1999; Lin 1999; Abushandi and Merkel 2011) and can be summarized as follows: (1) during flash floods, there is a rapid rising and falling of the water level; (2) it is difficult to install monitoring devices in the target area; (3) appropriate natural control sectors are nonexistent, artificial control in wadis is expensive; (4) extreme physical and climatologic circumstances exist; (5) sediment transport, moving rocks and debris can damage the installed instruments; (6) access is difficult due to few drivable roads, especially during the rainy and flooding seasons; (7) the population density in arid environments is typically low; (8) there is insufficient awareness of the 
importance of flooding studies and monitoring; and (9) the devices for flood measurement are expensive, especially in developing countries.

Not all flash floods are destructive, and the harvest of floodwater and rainfall-runoff for human and livestock usage and agricultural development should be considered by management in the construction of underground dams, artificial lakes, recharge dams and off-stream structures. Structures located unwisely in wadis are vulnerable to damage, and residents and tourists may be killed or injured, as vividly illustrated by the November 2009 floods in Jeddah (BBC 2009). Unfortunately, culverts, dams and other flood mitigation structures that have been designed and constructed in many wadis put significant numbers of people at risk. In the MENA region, very few researchers have considered the different alternatives for flash flood mitigation. Al-Weshah and El-Khoury (1999) compared various mitigation measures, including terracing, storage dams, construction of check, and afforestation, as well as different combinations of these measures using hydrological modelling tools. A master plan was proposed by McLane and Wüst (2000) to mitigate the flooding impact on the archaeological tombs of the Valley of Kings. An integrated approach using GIS and remote sensing was proposed for flash flood mitigation and water resource management in Safaga, Red Sea, Egypt. In this study, the prone area for flood risk was identified and mapped, the appropriate locations for dam construction were determined, and highly potential sites for water recharging were determined. Additionally, various rainfall-runoff analyses and discharge forecasting were conducted, and the inundation areas were identified. To date, no comprehensive proper strategies for mitigating and managing water resources have been developed in wadi basins. Establishing guidelines and integrated methods for the management and mitigation of wadis for potential future development projects is urgently needed to utilize floodwater as an additional water resource in arid areas.

The ISFF project is focused on disaster risk reduction (DRR) by discussing existing mitigation strategies for flash flood protection and consequent proper floodwater management (water harvesting) in arid countries in Egypt, Oman, Saudi Arabia, Yemen, Sudan, Jordan, and Morocco. Priorities will be defined for future research challenges, gaps, and potential projects for flash floods in wadi systems. ISFF projects have different objectives: (1) to initiate a networking platform for sharing knowledge, data, and experience among researchers, scientists, and authorities in the MENA countries, (2) to boost collaboration among researchers in both fundamental and applied sciences, and (3) to transfer Japanese technologies to the MENA region for FF protection and water harvesting.

The current chapter aims to present the current status of wadi flash floods in some parts of the MENA region, provide a state-of-the-art summary of current management and existing WFF mitigation strategies, present and discuss the approach of integrated flash flood management, and discuss the main research challenges to be addressed in future years. 


\subsection{ISFF Project}

The ISFF project was originally initiated by The Water Resources Research Center (WRRC) and the Global Alliance of Disaster Research Institutes (GADRI) of the Disaster Prevention Research Institute (DPRI), Kyoto University, to discuss the research outcomes of the MENA region and to establish research projects with several Arabian countries, including Morocco, Tunisia, Jordan, Egypt, Morocco, Oman, Saudi Arabia, Tunisia, Sudan, and Jordan. The first ISFF was organized at Kyoto University from 14 to 15 October 2015. The main purpose was to bring together researchers, scientists, and experts from governmental and private organizations in Japan, Sudan, Saudi Arabia, Egypt, Jordan, Oman, and Europe to initiate a scientific platform to discuss different topics related to flash floods, including hydrometeorology, flood disasters, and risk management, and to boost the foundation of joint research cooperation programmes. The ISFF was established to fill the current gaps in flash flood knowledge and to confirm a proper integrated strategy for water resource management in wadi systems. Several related topics have been addressed from different aspects, including water harvesting, mitigation measures (structural and non-structural), hydrological modelling, and early warning systems.

The main outcomes of the first ISFF symposium were drawing a roadmap for the next five years to support and continue the efforts of organizations and governments and to implement more scientific research and propose guidelines for assessing, mitigating and utilizing flash floods. In the symposium, a training course under the framework agenda of the UNESCO Japanese Fund-In-Trust (JFIT) project was organized with the title "Urgent Capacity Development for Managing Natural Disaster Risks of Flash Floods in Egypt, Jordan, Sudan and Yemen". Many participants from developing countries joined the course, which focused on flash flood management and prediction using the integrated flood analysis system (IFAS) and the rainfall-runoff-inundation (RRI) model designed by the International Centre for Water Hazard and Risk Management (ICHARM), Japan. This training was planned to foster the participants' awareness of WFF risk assessment and management.

Based on the road map, the second ISFF was organized and hosted by the TUB, El Gouna campus, Egypt, with the support of the UNESCO project. The third ISFF was organized in 2017 at GUTech in Muscat, Oman. It was mainly concentrating on flood risk mitigation, management, and assessment. The fourth ISFF was organized in 2018 at Hassan II University, Casablanca, Morocco. From 25 to 28 February 2020, the fifth ISFF was organized and hosted at WRRC, DPRI, Kyoto University, Japan. The fifth ISFF symposium was focused on wadi flash flood challenges in arid regions and especially "Disaster Risk Reduction and Assessment for the Flood Prone Urbanized \& Archaeological Wadis in Middle East and North Africa MENA Region". During the symposium, a special seminar on flash flood risk at UNESCO World Heritage Sites (WHS) was held on 26 February 2020. Due 
to COVID-19, the number of participants was limited, with approximately 87 from 12 countries. The sixth ISFF will take place in Amman, Jordan, from 26 to 30 September 2021. The continuity of such ISFF special annual meetings is desperately needed to overcome the water-related challenges in the MENA region.

\subsection{Extreme WFF Events and Disasters in Wadi Systems in the MENA Region}

The arid areas in the MENA region are typically hot and dry deserts (Fig. 1.1a) with rare to intermittent rainfall. However, the climate is variable according to the topography of each country (compare Fig. 1.1a-c), and extreme rainfall events are a crucial part of the region's climate (De Vries et al. 2018). Various examples of different wadi climates in Egypt, Morocco, and Oman are shown in Fig. 1.1. The infrequent storms recharge the freshwater storage, supporting agriculture and sustainable development, as shown in Wadi Samail (Fig. 1.1c). However, they can also be transformed into deadly and economical disasters in a short time. Flash floods in arid wadis are distinguished from other types of urban and river flooding by the following characteristics: (1) the dry stream channel is characterized by the absence of base flow (Fig. 1.1a) (Abdel-Fattah et al. 2018); (2) wadi surface runoff presents discontinuous flow due to short-duration rainfall events with highly localized spatial extent (Wheater et al. 1991; Saber 2010; Saber et al. 2010a, b, 2015); (3) the flow volume from single events is high, starting with low flow before the ascending hydrograph and increasing to the maximum peak of discharge before flow recession (Knighton and Nanson 1997; Saber and Habib 2015); (4) the evaporation rate, permeability of the desert, recharge of ground surfaces, sediment yield and slope are high; (5) plants and organic material are scarce, and soils are thin and poorly developed (McIntyre and Al-Qurashi 2009; Camarasa-Belmonte 2016); and (6) monitoring (rainfall, water level and discharge rates), accurate prediction, planning and strategies are lacking.

Extreme WFFs in the MENA region are characterized by high spatiotemporal variability in terms of frequency and intensity (Saber et al. 2017a, b, 2020). In the wadi systems of Arabian countries, a total of 50 flood events were recorded between 2000 and 2018, as shown in Fig. 1.2. The regional events in 2010, 2015, and 2018 affected more than one country. For instance, a single event in November 2018 affected Kuwait, the UAE, Oman, Qatar, Saudi Arabia, and Jordan, and extreme impacts occurred in most of the region. Figure 1.2 shows the total number of events in each country in the MENA region. More events occur in Saudi Arabia and Jordan due to cyclones. 

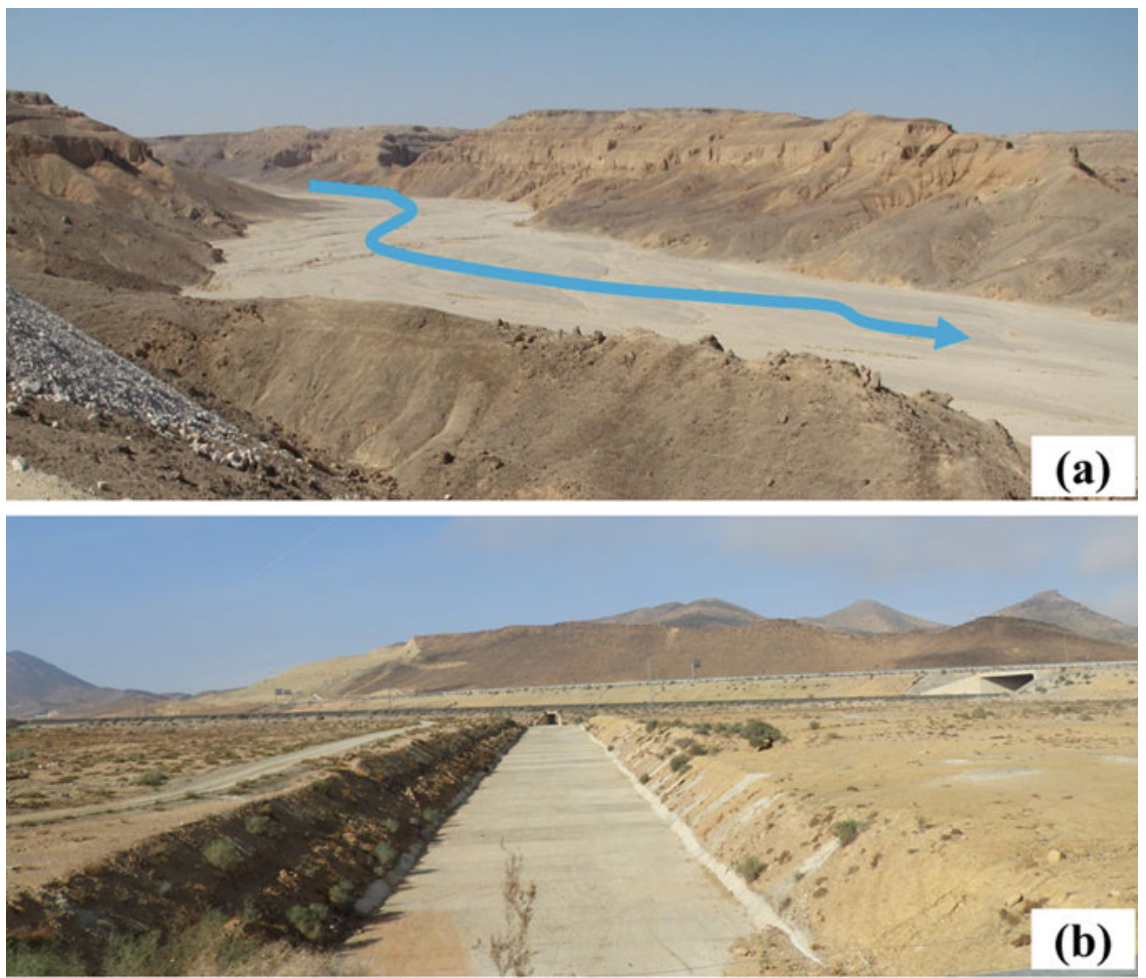

\section{Floods are damaging and difficult to quantify}

\section{High evaporation rates}

\section{Data are limited in extent $\&$ quality}

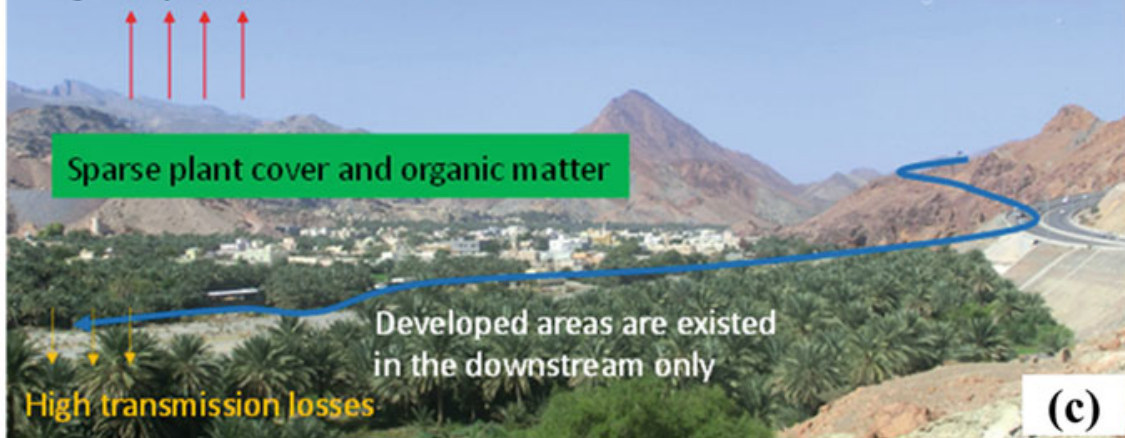

Fig. 1.1 Arid wadis system in a Wadi Qena (Egypt), b Oued (Wadi) El-Abed (Morocco) and c Wadi Samail (Oman) 

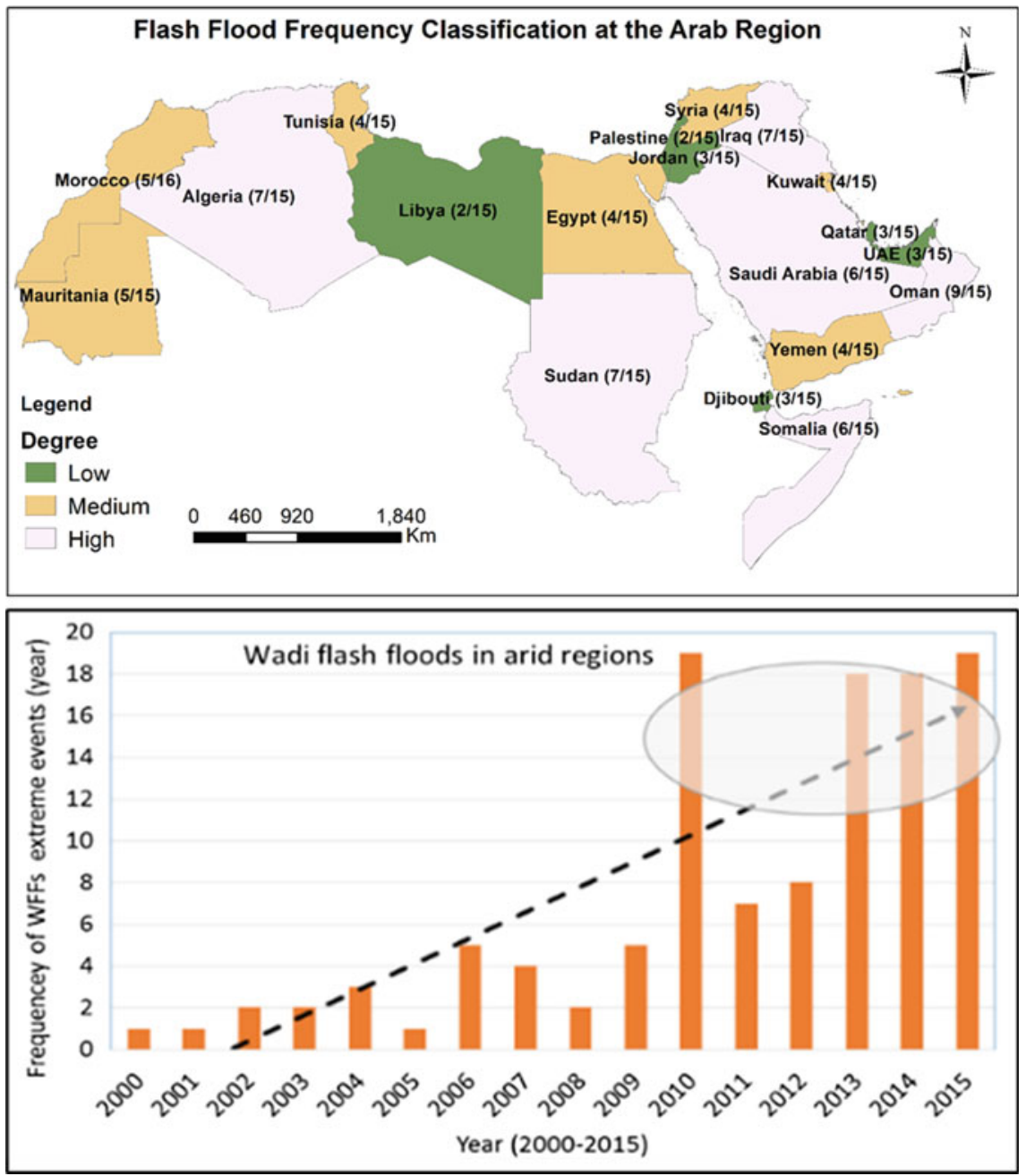

Fig. 1.2 Extreme flash floods events in the Arab region (2000-2018) showing the degree of flood frequency (upper panel) and the increasing trend in floods within the last two decades (lower panel)

\subsection{Spatial and Temporal Distributions of Wadi Flash Flood Events}

A recent study by De Vries et al. (2018) reported that tropical-extratropical interactions are the main drivers of extreme precipitation events in the MENA region. Therefore, understanding the variability of extreme rainfall events that mostly form flash floods is crucial to improving physically based forecasts and DRR. Figure 1.3 

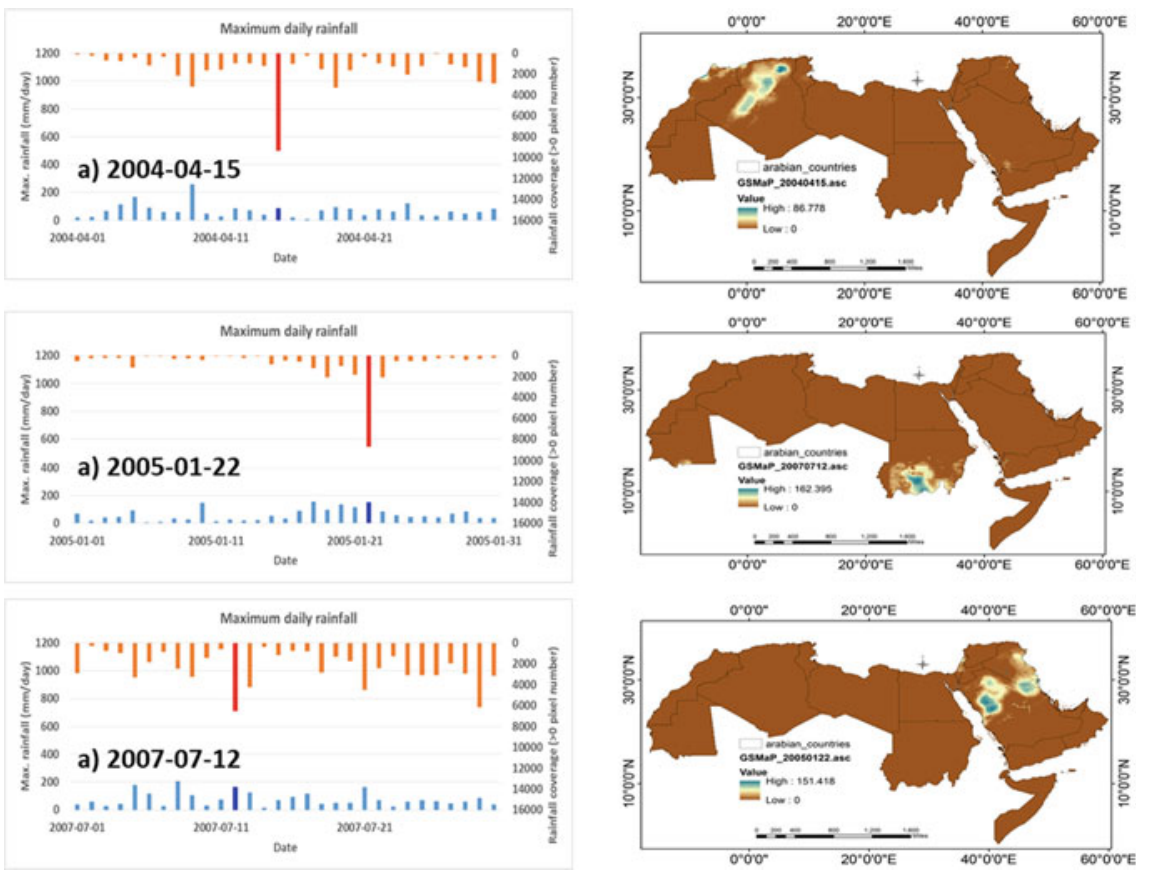

Fig. 1.3 Comparative analysis of 3 selected extreme events identified based on the maximum rainfall per day

shows the maximum spatial (Algeria, Arabian Peninsula, and Sudan) and temporal rainfall for three extreme events based on satellite rainfall datasets. The high variability in spatial coverage and intensity for the daily time series was investigated. Spatially, the first event over the northeastern part of the region produced a maximum rainfall rate of approximately $86.778 \mathrm{~mm} /$ day, the second event affected the Arabian Peninsula with $151.40 \mathrm{~mm} /$ day, and the third event over Sudan involved approximately $162.4 \mathrm{~mm} /$ day. These WFFs were highly variable depending on the climate and topography of each region.

\subsection{Rainstorms and Tropical Cyclones from the Indian Ocean}

MENA countries represent different climatic, hydrological, land use, and observational characteristics and storm types. WFFs in most of the region are produced by convective clouds at the end or beginning of winter and summer, when hot air masses cause heavy rainfall connected with thunderstorms except for the Arabian Peninsula, which is affected additionally by tropical cyclones. Most of these cyclone tracks develop over the Indian Ocean and Arabian Sea from April to June 


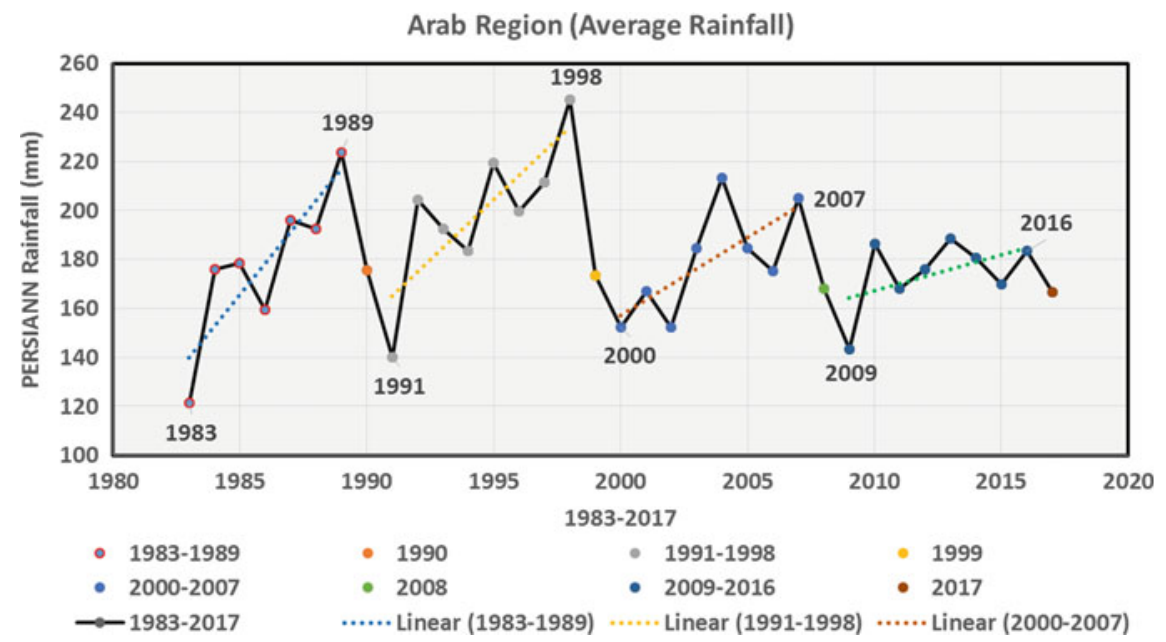

Fig. 1.4 Annual average rainfall over the Arabian countries from PERSIANN data

and October through December. For instance, Egypt has a very dry and arid climate with low annual average rainfall $(<50 \mathrm{~mm})$, whereas Oman has semi-arid to arid climatic conditions and a higher annual average rainfall of 50-350 mm. In Oman, WFFs are mainly discharged to coastal drainage systems. Figure 1.4 shows the annual average spanning 35 years over Oman associated with the total rainfall during cyclones. Records show that severe damage occurred in Oman in 1989, 1997, 2002, 2003, 2007, 2010, 2015 and 2016 (Al Barwani 2015) due to WFFs. The most extreme rainfall events that occurred in Oman were due to tropical cyclones Gonu-2007 and Phet-2010 (Al Barwani 2015; MRMWR 2015), which caused 56 fatalities with 6 billion USD of economic losses. Several wadis (W. Kabir, W. Aday and W. Samail) in Oman have experienced flash floods with huge impacts on the human life, infrastructure and property (Al-Rawas and Valeo 2008). Detailed hydrological research studies are desperately required to assess flash flood risks and propose effective mitigation measures in the MENA region.

\subsection{Impacts of Extreme Event Occurrences on Management}

Flash floods in arid environments can be dangerous because when rain falls on unabsorbent or clay soils, the amount of runoff increases and exceeds the wadi channel capacities (Saber 2010). Topographic factors play a significant role in the evolution of rainfall that causes flash floods. There are different issues that have a critical impacts on the occurrences of flash floods, including rainfall intensity and duration, topography, soil conditions and terrain. Topographic features, such as 
steep slopes, highland terrains and narrow valleys, increase the flash flood probability and accelerate surface runoff. The surface runoff is also affected by shallow watertight geological and saturated soil layers. Urbanized and affiliated construction with water-tight materials are supposed to generate runoff several times greater than that in natural coverage terrains (meadows, fields, and forests). Another flash flood hazard source is transported sediments and debris during flooding. Debris flow impacts can be explained as follows (Hungr et al. 1987): (1) hazards of the direct and indirect influence of high-energy, coarse-grained debris that can adversely affect structures and (2) hazards of debris deposits associated with the flood waters leading to the erosion of vulnerable surfaces and consequently flood damage.

The rapid increases in urbanization, population, and touristic and economic developments have pushed residences to build in vulnerable risk zones, including wadi flood plains. Figure 1.5 shows the present status of flash floods in different countries in the MENA region and different times of flood events. Flash flood management and the determination of flood-prone regions are extremely important due to residential development on hill slopes and at outlets of wadis as well as the lack of previous studies addressing flood hazard assessment given the infrequent occurrence of rainfall and the absence of well-defined watercourses. In general, most low-lying urban centres are flood-prone areas, which consequently require assessment and management using advanced techniques. Many cities have been affected by such flash flood events, such as Taba in Sinai and Wadis Abu-Shieha,
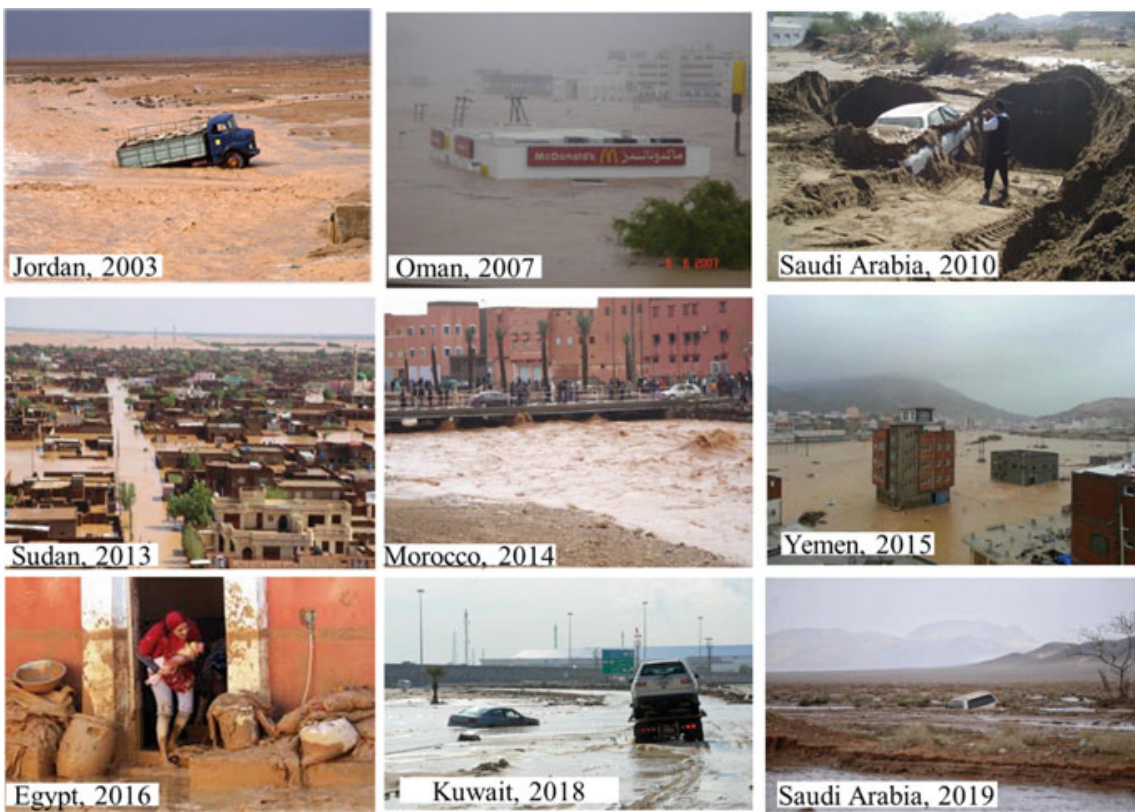

Fig. 1.5 a The affected areas by flash floods in Rafah, Sinai, Egypt, on 20 January 2010 (C Photo courtesy AF) and b Taba and Nweba flash flood in May 2010 (C El-Masry Elyoum) 


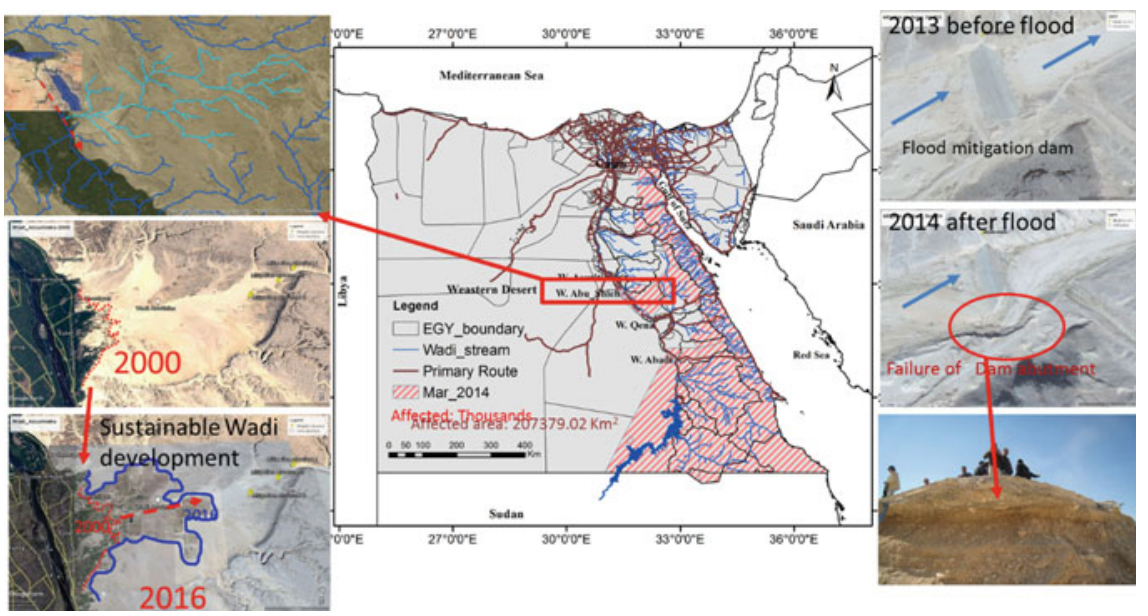

Fig. 1.6 The downstream delta of Wadi Abou Sheih along the river Nile, showing the extension of urbanization and agriculture reclamation (left panel) and the affected mitigation dams (right panel). Modified from Saber et al. (2017a, b)

Sohag, Aswan and Kom ombo along the River Nile. Wadi AbuShiha, one of the most important wadis in the Eastern Desert of Egypt, has suffered from many flash floods. It is characterized by many sub-basins (Fig. 1.6) in the downstream region, with many urbanized areas and agricultural reclamation projects. The downstream delta of the wadi is very large and has many new sites of urbanization, agriculture reclamation started in 2000, and the extension of agricultural lands increased to cover a much larger area in front of the outlet of the wadi, which is prone to flash floods, as shown in Fig. 1.6 (Saber et al. 2017a, b). Due to the importance of this downstream development in the wadi, the government constructed three mitigation dams (Fig. 1.6). However, after the 2014 flash flood, the first dam was broken at the abutment. Considering the climate change impacts and increased urbanization and reviewing the wadi management according to the occurrence of events are important, as well as enhancing the design codes for integrated management.

In summary, several factors contribute to flash flood risk, including human intervention and non-human actions. The flash flooding phenomenon is one of the most difficult natural hazards to predict and manage. As a result, responding appropriately is challenging for the concerned communities and authorities, and response plans are also essential (APFM 2007). During a flash flood, the water levels in streams rise suddenly, and the flow velocity can be very high. The strength of the water can be strong enough to uproot trees, move boulders, and destroy buildings and bridges located in its pathway. Water flowing often changes the morphology and riverbed characteristics and can consequently appear in locations where it usually does not. Water at a depth of $1 \mathrm{~m}$ depth and speed of $1.0 \mathrm{~m} / \mathrm{s}$ can pose a destructive threat for an adult person; flash floods often flow at very high speeds, and a water level of merely a dozen cm can be very hazardous (APFM 
2007). Early warning systems could be the significant element in dropping the risk to human lives and their properties. Conventional forecasting approaches cannot provide satisfactory warning, and people have insufficient time to move away from the floods.

\subsection{Hydrological Measurements of Wadi Systems and Flash Flood Forecasting}

Forecasting of WFFs is only the beginning to correctly design flood mitigation structures and develop efficient warning systems (Abdel-Fattah et al. 2018). Few wadis in the MENA region are equipped with hydrological monitoring stations for rainfall, water level and discharge rates (Al-Mamari et al. 2019). Therefore, calibrating and validating the computed runoff discharge and inundation depths in wadi systems are difficult. Such limited data availability in the wadi systems has resulted in the improper design and selection of mitigation structures, such as embankments, culverts, dams and drainage systems (Al-Mamari et al. 2019). Thus, the development of hydrological monitoring techniques is needed in the MENA region to improve wadi management and utilize measurements for prediction and evaluation. Figure 1.7 depicts an integrated list of the potential sensors and techniques to monitor spatial rainfall variations with rainfall radar and for continuous monitoring

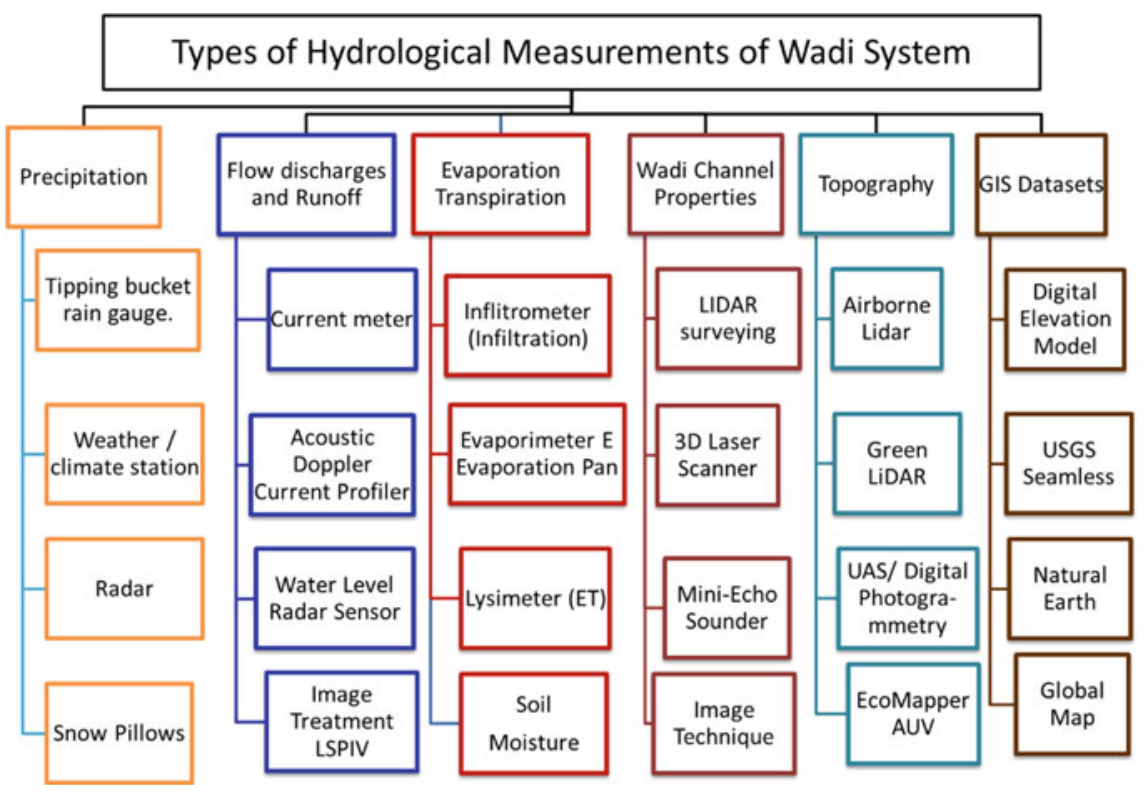

Fig. 1.7 Ad hoc hydrometric network and potential hydrological sensors/techniques 

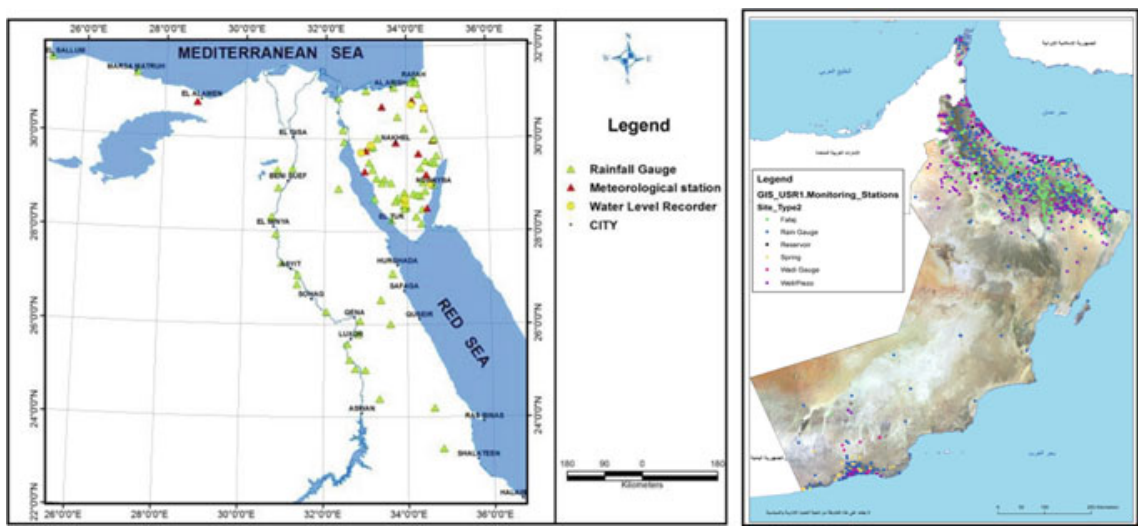

Fig. 1.8 Available wadi monitoring stations in Egypt (left panel) and Oman (right panel). Sources The National Water Research Center in Egypt and Ministry of Regional Municipalities and Water Resources in Oman

of water levels, soil moisture and infiltration using radar sensors and ultrasonic devices to measure flow velocities and calculate discharges. Moreover, the available techniques for the direct measurement of evaporation rates and remote sensing systems produced spatial datasets for different applications in hydrology (Tomsett and Leyland 2019). Wadis present various challenges to installing rain gauges and measuring flow, Therefore, there are a limited number of wadi monitoring stations in Oman and Egypt except for the rain gauges, water flow, and ground water wells (Fig. 1.8).

\subsection{Image-Based Techniques}

Monitoring systems that use recorded videos have the advantage of capturing real-time floods so that the flow discharge can be computed, which can help in flood management. The implementation of large-scale particle image velocimetry (LSPIV), which is an image-based technique, was recently accomplished for the first time in Oman at Wadi Samail (Al-Mamari et al. 2019). Various fixed cameras have been installed on the bridges crossing the wadi channel, and they can record the surface flow movements. LSPIV based on drone images is now common in many applications among the river engineering community, such as for time-averaged surface velocities. The rapid development of unmanned aerial systems (UASs) has allowed us to measure streamflow in real-time with high spatial and temporal variations (Tauro et al. 2016). To capture valuable information about the river hydraulic conditions during flash floods in humid environments, a UAS was successfully utilized by Perks et al. (2016). The potential of UASs during low-flow conditions was demonstrated by Detert and Weitbrecht (2015). 
A considerable amount of literature on using photogrammetric techniques to monitor riverbed morphology and riverbanks has been published (Brasington and Smart 2003; Bird et al. 2010).

\subsection{Risk Assessment Methods}

El Shamy (1992) developed a method to evaluate the flash flood possibility and groundwater recharge in several sub-basins, employing various geomorphometric parameters, such as the drainage density, drainage frequency, and bifurcation ratio. This model has since been adopted by many studies (Youssef and Hegab 2005; El-Behiry et al. 2006; Arnous et al. 2011; Abdel-Lattif and Sherief 2012; Abdalla et al. 2014). Abdel-Fattah et al. (2017) proposed a consistent methodology applied to assess flash floods in Wadi Qena, where field data are limited. Flash flood consequences include environmental and economic issues because these floods may cause impairment to urbanized and agricultural regions as well as lead to the loss of human lives (Merz et al. 2010). The increasing frequency of destructive flash floods requires an ongoing enhancement in the identification and mapping of flood hazards (Kundzewicz and Kaczmarek 2000; Ebert et al. 2009). Al Saud (2010) used high-resolution satellite images to identify the 2009 flood damage in Jeddah City, KSA. Omran et al. (2011) used the standardization of morphometric parameters with the same weight for basin-based flash flood hazard assessment in Wadi Dahab, Sinai Peninsula, Egypt. The same method was applied in Wadi Al Lith (Bajabaa et al. 2014) and at Wadi Rabigh, Wadi Yanbu, Wadi Khulais, Wadi Jizanhe, Wadi Baish, and Wadi El-Qunfza in the KSA (Shi 2014). By integrating geomorphology and geology along with remote sensing techniques and field observations, geomorphological hazard assessments based on GIS have been performed in several areas in Egypt, including the area between Quseir and Safaga near the Red Sea, using the El-Shamy model (Youssef et al. 2009), and along the Katherine-Feiran road in South Sinai (Youssef et al. 2011).

To reduce the flood damage impacts of FF hazards, proposing proper dam sites have been proposed for several urban areas. The probability of flood hazards has been estimated for different catchments based on geomorphometric features (El Shamy 1992). Further, geomorphometric-based studies have been conducted to assess FF risk levels in many basins. For instance, El-Magd et al. (2010) used remote sensing data and GIS tools combined with morphometric parameters to assess FF hazards in the Abu Dabbab wadi basin. Then, all the datasets were integrated as inputs for a hydrological model to estimate surface runoff and identify the flood risk levels.

Sen et al. (2013) proposed a procedure for establishing flood inundation maps in the southwestern Kingdom of Saudi Arabia using surveyed cross-sections of the flood plain. The main geological hazards, flash flood causes, and main rainfall events in the KSA were summarized by Youssef and Maerz (2013). An analytical hierarchical process (AHP) was used by Elkhrachy (2015) to estimate the flood 
hazard index in Najran, Saudi Arabia, employing the main controlling parameters of flash floods, such as the channel discharge, soil type, drainage density, surface roughness, surface slope, distance from main streams and land use. An AHP was further used by Youssef et al. (2015) to utilize variant geological, geomorphological, and geographical features in an approach to understand the effects of urban development in Wadi Al-Aska, Jeddah, KSA. Abuzied et al. (2016) used multisource geospatial data with remote sensing techniques, GIS analyses, and field investigations to evaluate flash flood hazards in the Nuweiba area based on basin morphometric analysis and hydrological modelling indices using the Soil Conservation Services (SCS) method.

\subsection{Wadi Hydrological Modelling and Approaches}

The major limitation of furthering our understanding of wadi flood events is that in most wadis, hydrological measurements do not exist. Most researchers have conducted flash flood analyses using simplified hydrological models. These models mathematically represent various hydrological processes, such as surface and groundwater processes, and are essential tools for water resources management (Abdel-Fattah et al. 2017). Hydrological models are desperately needed due to the limited measurements and the intricacy of hydrological systems (Beven 2011). The selection of the hydrological model approach relies on the number of measured parameters and the required observational data for the input model parameters and catchment characteristics (Abushandi 2011). Most WFFs in arid regions have been studied using lumped or semi-distributed models with very few applications based on distributed models because these models are data-driven. Various challenges remain to validate and calibrate the developed models in arid regions (Cools et al. 2012; Abdel-Fattah et al. 2018), to improve the reliability of the results, and to conduct a sensitivity analysis of the model parameters.

\subsection{Utilized Hydrological Models in Arid Areas}

Few hydrological models have been adopted and developed for flash flood modelling in wadis, such as the applied models in wadis in Oman, including the RRI model (Abdel-Fattah et al. 2018), the KINEROS2 model (Al-Qurashi et al. 2008), and the IHACRES model (McIntyre and Al-Qurashi 2009), as well as the soil water assessment tool (SWAT) in the UAE (Al Mulla 2005; Abushandi and Merkel 2011) and the HEC-HMS model in Oman, the West Bank-Palestine and the UAE (Al-Rawas and Valeo 2008; Shadeed and Almasri 2010; Sherif et al. 2010).

In addition to the aforementioned studies, several trials have been conducted, such as that by Al-Weshah and El-Khoury (1999), who applied and calibrated the HEC-1 model utilizing the SCS and curve number $(\mathrm{CN})$ methods in the Petra 
region, Jordan, and further used these hydrological modelling tools to determine the impact of several mitigation scenarios. Abdulla et al. (2002) developed a watershed model for a simple single event to predict surface runoff in the western part of Iraq. In Saudi Arabia, a geomorpho-climatic model has been adopted (Al-Turbak 1996), in which rainfall duration and intensity are estimated in three catchments from the infiltration parameters. In Palestine, (Lange et al. 2000) focused on the rainfall-runoff modelling of single flood events. It was stated that the analysis of a single storm event is highly recommended to understand extreme floods in arid environments. The HEC-HMS model and the spatial water budget model (SWBM) were employed in the Zarqa River Basin to manage water resources (Al-Abed et al. 2005; Abushandi and Merkel 2011; Dawod et al. 2011, 2012), and the SCS and CN methods in GIS have been used to assess flash floods, to determine the impacts of some basin geomorphometric parameters on the estimated flood characteristics in the Makkah metropolitan region, and to classify the flood hazard degree on city roads.

Foody et al. (2004) predicted sites at risk from high peak flows accompanying flash flooding in wadis intersecting the Idfu-Marsa Alam road (near the Red Sea) using the HMS model and field observations of the soil texture and infiltration capacity. This study was further updated using the same model setting by Ghoneim and Foody (2013) to investigate the impact of flood sites, areal coverage, and rainfall depth. El Bastawesy et al. (2009) presented an integrated method using ArcGIS and remote sensing data for modelling flash floods, where Landsat images can be used to distinguish flooded and non-flooded areas. The physical hydrological parameters, including rainfall, infiltration, land use and soil types, must be taken into consideration. Flash flood simulations for some rainfall events at wadis of the River Nile were conducted by Saber et al. (2010a, b) using Hydro-BEAM integrated with remote sensing and satellite datasets. In the study of Ismail et al. (2010), GIS, morphometric parameters and rainfall-runoff modelling based on flood routing processing (FRP) were integrated and employed to simulate the flow discharge at Wadi Abu Ghusun, the Eastern Desert, Egypt. Kehew et al. (2010) reconstructed extreme flash floods in Wadi Isla, South Sinai, Egypt, using palaeohydrological indictors related to flood velocity and discharge, such as the size of boulders transported within the wadi. Additionally, the calibrated SWAT model was used to estimate the amount of rainfall required to generate a flood. The flood hazard levels and ground recharge potentiality have been assessed at W. Abadi (Ibrahim et al. 2011). Based on field measurements of paleo-flood events and the rating curve, the peak flow of the January 2010 flash flood event was estimated, and this discharge peak was then used for model calibration. Hydrological modelling conducted in Wadi Hodin used the HEC-1 model by Soussa (2012) and the SCS method to calculate the losses. Hadadin et al. (2013) used routing and Snyder synthetic unit hydrograph methods to estimate the peak flow in 12 main basins in Jeddah City, KSA. Fathy et al. (2015) developed a lumped model for arid watersheds and compared the results with those from the watershed modelling system (WMS). This model was applied to W. Sudr in the Sinai Peninsula. The peak runoff discharge of six basins in western Saudi Arabia was estimated by Shi (2014) using three 
empirical models (Farquharson's model, Nouh's model and Al-Subai's model) and the Snyder unit hydrograph. Moreover, Abuzied (2016) conducted hydrological modelling at Wadi Watier using the SCS method.

\subsection{Surface Runoff Interaction with Groundwater}

Many studies have examined groundwater recharge due to rainfall events and surface runoff. For instance, Gheith and Sultan (2002) estimated groundwater recharge in the alluvial aquifers of several wadis in the Eastern Desert of Egypt (W. El-Arish, W. Asyuti, W. Tarfa, W. Qena, and W. Hammamt). In this study, a hydrological model that considers the spatiotemporal rainfall distribution, appropriate sub-basin unit hydrographs and infiltration parameters were utilized to calculate initial and transmission losses and runoff. The model incorporated geological and meteorological datasets along with remote sensing and GIS techniques. Milewski et al. (2009) modelled runoff and groundwater recharge based on remote sensing datasets by focusing on the heavy rainfall events between 1998 and 2007 for the main wadis of the Sinai Peninsula and Eastern Desert. In the studied catchments, the annual precipitation, runoff, initial losses, and recharge through transmission losses were assessed. This approach has also been utilized to calculate the annual groundwater recharge at the Nubian Sandstone aquifer, South Sinai (Sultan et al. 2011). A proper example of cost-effective and practical integrated solutions, including geophysics, geochemistry, and modelling, that utilize global remote sensing datasets and web-based GIS technologies was proposed by Becker et al. (2012) for the wadis of the Eastern Desert and Sinai Peninsula, Egypt. The study implemented approaches to develop a conceptual model for hydrogeological settings in different aquifers to assess the annual runoff and recharge using a hydrologic model of the main watersheds.

The potential sites for surface runoff recharge in Sinai have been determined using an integration of GIS, remote sensing, and watershed modelling to introduce a multi-criteria decision support system that includes several parameters, such as the flood volume, average overland flow distance, lineament frequency density, soil infiltration, and morphometric parameters. The potential areas for rainwater harvesting have been determined based on such criteria by conducting weighted spatial probability modelling. The potential sites for water harvesting have been determined by applying Finkel-SCS rainfall-runoff approaches (Elewa et al. 2012). Furthermore, the same approach has been utilized to recommend proper dam locations for flood management and control at Wadi El-Arish. Technical considerations and design criteria have been introduced for the planned mitigation structures (Elewa et al. 2013).

To estimate surface runoff and groundwater recharge, the relationship between runoff and rainfall has been assessed depending on paleo-flood indicators. Two methods have been tested to evaluate the relationships between rainfall and runoff at the El-Hawashyia basin and Ghazala sub-basin in the Gulf of Suez, Egypt. Some 
morphometric parameters with direct effects on flooding have been analyzed to evaluate the flood risks, and their relationship with flash floods has been investigated (Masoud 2013).

Al Zayed et al. (2013) assessed the potential of flood water harvesting at Wadi Watier in South Sinai, Egypt. The study was conducted based on the integrated guidelines of water resource management (IWRM). Thus, physical and environmental investigations along with social and institutional analyses were conducted. The flow discharge was calculated using the Hydrologic Engineering Centre (HEC-1) model; then, the potential sites were determined in ArcGIS by combining several factors, including slope, geology and land use.

Therefore, a new methodology urgently needs to be proposed to address the abovementioned challenges, to assess and predict flash flood disasters in arid wadis, and to evaluate the various flood mitigation strategies.

\subsection{Mitigation Measures Against Wadi Flash Floods}

Substantial efforts have been undertaken by governments and the private sectors of the MENA countries to enhance flash flood mitigation structures and early warning systems, while WFFs continue to be one of nature's worst killers in this region. Within the ISFF project, we can conclude that critical infrastructure and houses are newly allocated by the government and are often located in wadi channels because the wadi floors are flat and construction material is available. We find that this infrastructure is constructed in the path of flooding leading to a narrow channel to convey floodwaters along streams, in addition to the existence of important infrastructure and houses situated on higher lands. Such settlements are also affected by floods because the population chooses flood-sensitive economic, cultural and social activities (McBain 2012; Sayers et al. 2013). Understanding the contribution of structural and non-structural measures on flood risk reduction could support proper decision making and future planning (Shah 2015). Usually, the main structural measures in wadis rely on an 'embankment only' option that has been broadened to integrate other options, such as improvements to drainage channels, diversion dykes, detention and flood storage dams.

Flood risk reduction can be accomplished by controlling the flood magnitude flood-prone areas (Heidari 2009), where flood mitigation measures can be categorized into non-structural and structural measures (Hansson et al. 2008; Heidari 2009). Non-structural measures refer to non-engineering actions, such as increasing preparedness through early warnings, using insurance, land use, restricting development, planning and operating flood control reservoirs (Hansson et al. 2008; Shah et al. 2015). Structural defence strategies can be either conventional measures, such as dams and levees, or extensive ecosystem-specific measures, such as restoration of natural conditions (Hansson et al. 2008). Furthermore, structural measures can be important for managing water and controlling hazardous floods (Ho et al. 2017). 
Flood mitigation strategies should consider the following issues (HEC 1998; Heidari 2009): (1) a proper implementation approach for flood control; (2) an appropriate site for facility installation; (3) an appropriate facility size; and (4) effective maintenance and operation of the facilities. In Egypt, most highways, roads and other infrastructure have been constructed across wadis that surround the main cities. Currently, no inclusive proper protection from flash floods is applied at most wadis in Egypt. Although comprehensive protection from flood risks is not feasible, the flood disaster risk could be decreased by (1) reducing the exposure by preventing or moving the development activities in areas where the hazards are high, such as floodplains; (2) reducing vulnerability by establishing resilient infrastructure standards and design and sound disaster preparedness measures; and (3) reducing the hazard itself, in some cases, by the construction of flood mitigation measures.

\subsection{Structural Measures}

Based on the spatial scale, structural mitigation measures can be categorized into distributed and concentrated measures. Several past studies have discussed distributed structural measures for flood mitigation (Andoh and Declerck 1997; Montaldo et al. 2004; Emerson et al. 2005; Kurz et al. 2007; Ravazzani et al. 2014; Thomas 2015). The main goal of distributed structures is to alleviate the flow peak and store excess floodwaters in the upstream sub-basins to reduce the discharge in the downstream areas (Montaldo et al. 2004; Thomas 2015). Distributed reservoirs have been shown to reduce the flow peak magnitudes based on distributed models (Chennu et al. 2007; Del Giudice et al. 2014), semi-distributed models (Ramireddygari et al. 2000; Leblois et al. 2010) and analytic analyses (Del Giudice et al. 2014). Various studies have also used cost-benefit analysis for flood mitigation scenarios (Heidari 2009) or multi-criteria decision-making techniques (e.g., Ahmad and Simonovic 2006; Mostafazadeh et al. 2017). The reductions in the flow peak in these related studies vary extensively within the range from 0.3 to $36 \%$ (Emerson et al. 2005; Mostafazadeh et al. 2017; Ravazzani et al. 2014; Thomas 2015); however, in some cases of dry dams, the reduction in the flow peak was less than 50\% (Chennu et al. 2007). Onusluel Gul et al. (2010) studied the use of concentrated dams to evaluate the impact of flood mitigations on a downstream area using a combination of hydraulic and hydrologic modelling. However, the direct advantage of structural control measures, i.e., the sustainable efficiency of the structural flood control measures, cannot be maintained. For instance, several areas within large flood control projects have been affected by flooding immediately after their establishment. Further, flood mitigation measures often appeal to new development in flood-prone areas (McBain 2012; Shah et al. 2015).

Several measures have been adopted in Egypt to mitigate flash floods, such as the integration of detention and obstacle dams as well as artificial lakes, leading to well water management and flood mitigation. A field investigation was conducted 


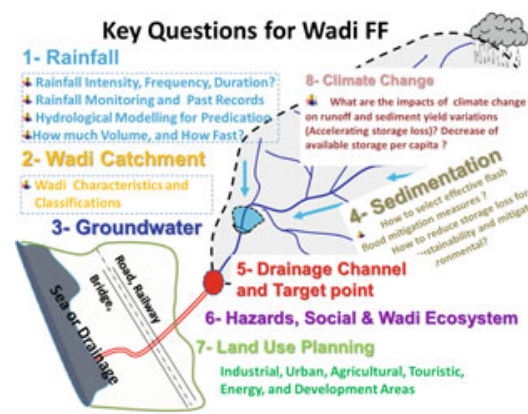

(a)

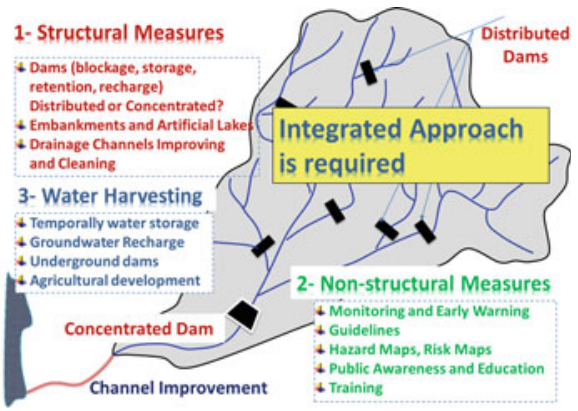

(b)

Fig. 1.9 The main challenges of wadi systems (a) and the requirement of an integrated approach (b)

by researchers and experts from both Kyoto University and the Japan Dam Engineering Center (JDEC) to investigate some wadi basins from 22 to 29 November 2014 along the Red Sea coast and the Eastern Desert, Egypt. The main purpose of such field investigations was to evaluate the current geological, hydrological, operational and structural conditions of the present flood control mitigation dams. This could be helpful for the selection of suitable integration measures and their structural design criteria as well as to clarify possible collaboration on selected pilot projects.

The Egyptian government makes master plans for water harvesting and flash flood mitigation, including long-term and short-term plans for low- and high-risk wadi basins. Different flood management structures have been implemented in Egypt, such as storage dams, obstacle dams, artificial lakes, diversion dykes, embankments, and artificial drainage channels, as indicated in Fig. 1.5. The proper selection of mitigation measures and their design are usually proposed based on the expected volume of flood water, risk and hazard degree, the prone and affected areas, and return periods.

Figure 1.9 shows the different characteristics of the main flash flood management and mitigation structures in both Egypt and Oman: (1) obstacle dams (less than 4-6 m) simply reduce the flood velocity, whereas (2) retention dams (approximately $10 \mathrm{~m})$ and artificial lakes $(2-4 \mathrm{~m})$ are mainly for water harvesting and flood retention.

\subsection{Non-structural Measures}

Non-structural flood control measures have been widely applied to decrease the flow peak via land-use changes, early warning, and reducing flood vulnerability and exposure (Tapsell et al. 2002; White and Richards 2007; Richards et al. 2008; Shah 2015). Recently, these strategies have been followed by increasing efforts for 
appropriate risk management to reduce flood hazards (McBain 2012; Sayers et al. 2013).

Unlike the immediate visualization of the advantages of structural flood defences, quantifying the efficiency of non-structural measures is often difficult. Owing to non-structural flood control measures, the adaptation and response of vulnerable communities to flood disasters vary widely and are influenced by several factors, such as community susceptibility and resilience to flooding. Additionally, the efficiency of non-structural flood control measures is sensitive to socio-economic changes and governmental arrangements (Dawson et al. 2011). However, non-structural control measures provide flexible flood mitigation measures for adapting to changes in river systems, climatic change and socio-economic impacts, which can hinder sustainable environmental development (Kundzewicz 2002).

\subsection{Preparedness and Emergency Planning}

The purpose of the preparedness stage is to provide the essential decision support system for the case in which the present flood protection system fails (Plate 2002). Obviously, there is no technical solution that is unconditionally safe in the context of flood control (Plate 2002). Even if the system always performs as expected, offering protection against any conceivable flood is rarely possible (Plate 2002). A residual risk always remains due to failure of technical systems or due to infrequent floods that surpass the design flood level. It is important to understand the flood risk in terms of safety and communication approaches for a better present and future development (Shah et al. 2015).

\subsection{Education and Modification of Human Actions}

The WRRC and the GADRI of the DPRI, Kyoto University, initiated ISFF and established several research projects to assess flash flood hazards and risks, to offer effective methodologies and techniques, and to highlight transdisciplinary approaches in the MENA region.

\subsection{Integrated Wadi Flash Flood Management and Strategies}

Efficient and sustainable flood mitigation measures (structural and non-structural) vary significantly according to the planning framework (Shah et al. 2015). In the short term, several structural flood management projects have confirmed their 
efficiency for mitigating floods; such contributions have led to confidence in protecting people from flooding impacts by engineering structures (Shah et al. 2015). In the long term, however, some structural control measures have been found to be inefficient during catastrophic flood events (Shah et al. 2015) due to unplanned developments, land-use changes, growing production levels, population growth, transportation and consumption, which have led to increased flood hazards (Jonkman et al. 2003). Flood fatalities have continued to increase; thus, more advanced approaches for flood risk management are needed (Hall and PenningRowsell 2011; Sayers et al. 2013; Shah et al. 2015).

In the early decades of the twentieth century, extreme flooding events motivated researchers and scientists to develop basin-scale flood mitigation measures and coordination policies for mitigating floods instead of local flood mitigation measures (Shah et al. 2015). Flood risk management is a constant adaptive management process (Hall and Penning-Rowsell 2011; Sayers et al. 2013); thus, dynamic sustainability approaches and concepts that involve adaptative interventions for accomplishing a suitable outcome via problem-solving and nonstop learning are highly recommended (Newman 2005; Scoones et al. 2007).

\subsection{Recommendations and Feedback from ISFF Participants}

A single management strategy is not sufficient to reduce flash flood risks; nevertheless, integration approaches for flood risk management are needed in wadi systems. The proposed integrated management approach (Fig. 1.10) addresses the development of strategic methodologies to assess the capability of mitigating flash floods and managing water resources using effective strategies and hydrological modelling (Kantoush et al. 2011; Sumi et al. 2013). Reducing flood disaster risk is a crucial concern for many countries worldwide. The management and mitigation of flooding remains a challenging task in many developed and developing countries (Shah et al. 2015), and existing global efforts and technological advancements still fall short. In most arid wadis, no comprehensive proper mitigation strategies for flash floods have been proposed. This situation is mainly due to the relatively low flood frequency compared to that of humid regions. With progress in international collaboration and data sharing, flood management strategies and approaches can be transferred from other experiences or countries and applied in arid wadi systems with customization for the unique characteristics of wadi systems, including the socio-economic situation. In this chapter, a critical review of the concepts, strategies and practices of flood risk management reveal new dimensions for developing and proposing sustainable and efficient management strategies in wadi systems. 


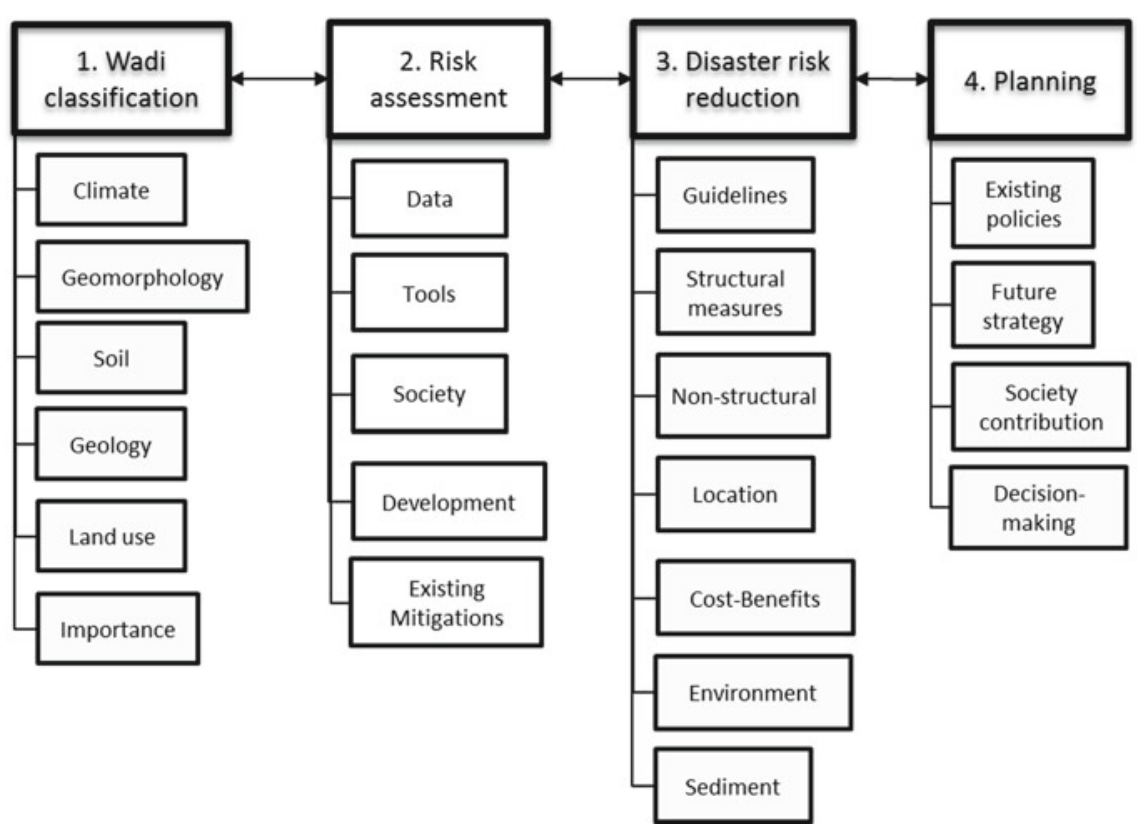

Fig. 1.10 Key components of integrated wadi flash flood management

\subsection{Research Challenges}

The current research has left several gaps, where more research and development need to be implemented to minimize future wadi flash flood risks. The main questions and challenges that are facing wadi systems are summarized in Fig. 1.9. Some such challenges are also addressed in the following sections.

\subsection{Methods}

The proposed approaches require further calibration and validation in the ungauged wadis of Egypt using rainfall and wadi flow observations in addition to applying similar approaches in other wadis with an extensive range of hydrological basin characteristics. In some models, such as the Hydro-BEAM model, kinematic wave models have been used, which are appropriate for steep slopes but do not work well in flat areas. Therefore, other techniques, such as diffusive and dynamic wave models, may provide better results. Moreover, the current time step adjustment in the Hydro-BEAM model is manually determined, consuming excess simulation time; therefore, an adaptive scheme for the Hydro-BEAM time step is recommended. The RRI model still does not have a stable groundwater module (under 
development), which is recommended to be included and validated. Due to data limitations, the RRI model inundation outputs have not been calibrated and should be considered in the future for a more comprehensive evaluation of the RRI model in wadi systems. The performance of more hydrological models should be compared and assessed to identify the best option in wadi systems. Fieldwork to investigate the infiltration capacity of different land-use types can be used to better calibrate hydrological models. Wadi channel transmission losses should be considered in future RRI models because these processes are essential in wadi systems. Defining flood events by a return period using frequency analysis (Stedinger 1993) has evolved from the application of simple methods to intricate ones to assess probabilistic flood scenarios considering the exceedance probability (Merz and Thieken 2004) and uncertainties (Merz et al. 2008; Wu et al. 2011; Shah et al. 2015); therefore, current flood risk assessments should be updated based on the return period. Other important criteria, including the effect of structural measures on the landscape, society, environment and habitat diversity, should be considered along with the addressed factors. Additionally, the developed dam standards should be updated to investigate water infiltration and siltation in reservoirs. Different methods of flash flood water harvesting should be proposed and adapted for sustainable water management. The proposed approaches for determining dam design and locations (dam height, reservoir volume and area) using digital elevation model data should be validated using field surveys. Moreover, the long-term prediction of climate change and anthropogenic impacts (such as land-use changes) on wadi flash foods is necessary.

\subsection{Mitigation Measures}

Focusing on soft flood mitigation measures (early warning systems and social awareness) helps minimize the loss of human life and infrastructure damage caused by flash floods. The evaluation of sediment transport during wadi flash flooding is also recommended because sediment has a severe impact on mitigation structures, which increases the flash flood risk and decreases the efficiency of flood mitigation structures. Therefore, studying this factor and linking it with wadi characteristics, such as geomorphometry and soil type, are important. Detailed flood risk assessment based on more land use and geomorphological features is highly advised. This study recommends an integrated approach for all wadi systems that includes 'dynamic sustainability' concepts for proper flood management planning (Fig. 1.10). Stakeholders and decision-makers have various options and approaches for flood-prone communities by sharing experiences and knowledge around the world (Shah et al. 2015). Therefore, we highly recommended that a database contains the available data from all wadi systems and be accessible to any researcher. 


\subsection{Conclusions}

Flash floods are damaging natural disasters and are an important source of water in arid areas, where flash floods can provide renewable freshwater, mainly for groundwater recharge. Therefore, using a proper decision support system based on efficient approaches could help manage infrequent floods. A flash flood can be created within a short time after a rainfall event, especially under certain geological and topographical conditions, such as steep topography with shallow, impermeable soils, bare rock and rare or sparse vegetation. The majority of the Great Sahara of North Africa and the Arabian Peninsula consists of hyper-arid environments with limited precipitation, where most countries suffer from water scarcity.

Flash flood disasters in arid environments are associated with several challenges that originate from many characteristics of a flash flood itself, arid environment characteristics, and data and methodology limitations. The different dimensions of flash flood phenomena, reasons and resulting impacts have been discussed in detail. Despite these challenges, several hydrological, geomorphological and disaster management aspects have been discussed in the context of wadi systems in this chapter.

\section{References}

Abdalla F, El Shamy I et al (2014) Flash floods and groundwater recharge potentials in arid land alluvial basins, southern Red sea coast, Egypt. Int J Geosci 2014

Abdel-Fattah M, Saber M et al (2017) A Hydrological and geomorphometric approach to understanding the generation of Wadi flash floods. Water 9(7):553

Abdel-Fattah M, Kantoush SA et al (2018) Rainfall-runoff modeling for extreme flash floods in Wadi Samail, Oman. J Jpn Soc Civ Eng Ser B1 (Hydraul Eng) 74(5)

Abdel-Lattif A, Sherief Y (2012) Morphometric analysis and flash floods of Wadi Sudr and Wadi Wardan, Gulf of Suez, Egypt: using digital elevation model. Arab J Geosci 5(2):181-195

Abdelkareem M, El-Baz F (2015) Analyses of optical images and radar data reveal structural features and predict groundwater accumulations in the central Eastern Desert of Egypt. Arab J Geosci 8(5):2653-2666

Abdulla FA, Amayreh JA et al (2002) Single event watershed model for simulating runoff hydrograph in desert regions. Water Resour Manage 16(3):221-238

Abushandi E (2011) Rainfall-runoff modeling in arid areas. PhD Thesis. https://citeseerx.ist.psu. edu/viewdoc/download?doi=10.1.1.458.8955\&rep=rep1\&type=pdf

Abushandi E, Merkel B (2011) Rainfall estimation over the Wadi Dhuliel arid catchment, Jordan from GSMaP_MVK+. Hydrol Earth Syst Sci Discuss 8(1):1665-1704

Abuzied S, Yuan M et al (2016) Geospatial risk assessment of flash floods in Nuweiba area Egypt. J Arid Environ 133:54-72

Ahmad S, Simonovic SP (2006) An intelligent decision support system for management of floods. Water Resour Manage 20(3):391-410 
Al-Abed N, Abdulla F et al (2005) GIS-hydrological models for managing water resources in the Zarqa river basin. Environ Geol 47(3):405-411

Al-Mamari MM, Kantoush SA et al (2019) Real-Time measurement of flash-flood in a Wadi area by LSPIV and STIV. Hydrology 6(1):27

Al-Qurashi A, McIntyre N et al (2008) Application of the Kineros2 rainfall-runoff model to an arid catchment in Oman. J Hydrol 355(1-4):105

Al-Rawas GA, Valeo C (2008) Issues with flash flood modeling in the capital region of Sultanate Oman. Geomatics Eng Schulich Sch Eng Univ Calgary 1-11

Al-Turbak A (1996) Geomorphoclimatic peak discharge model with a physically based infiltration component. J Hydrol 176:1-12

Al-Weshah RA, El-Khoury F (1999) Flood analysis and mitigation for Petra area in Jordan. J Water Resour Plan Manage 125(3):170-177

Al Barwani A (2015) Flash flood mitigation and harvesting Oman case study. In: First international symposium on flash floods (ISFF), Kyoto, Japan

Al Khatry A, Helmi T (2008) The effect of Gonu cyclone on recharging groundwater aquiferssultanate of Oman. In: The first international conference on water resources and climate change in the MENA region, Muscat, The Sultanate of Oman

Al Mulla M (2005) Application of a hydrological model in a data-poor arid region catchment: a case study of Wadi Ham

Al Saud M (2010) Mapping potential areas for groundwater storage in Wadi Aurnah Basin, western Arabian Peninsula, using remote sensing and geographic information system techniques. Hydrogeol J 18(6):1481-1495

Al Zayed IS, Ribbe L et al (2013) Water harvesting and flashflood mitigation-Wadi Watier case study (South Sinai, Egypt). Int J Water Resour Arid Environ 2(2):102-109

Alcántara-Ayala I (2002) Geomorphology, natural hazards, vulnerability and prevention of natural disasters in developing countries. Geomorphology 47(2-4):107-124

Andoh RYG, Declerck C (1997) A cost effective approach to stormwater management? Source control and distributed storage. Water Sci Technol 36(8-9):307-311

APFM (2007) Guidance on flash flood management: recent experiences from Central and Eastern Europe

Arnous MO, Aboulela HA et al (2011) Geo-environmental hazards assessment of the north western Gulf of Suez, Egypt. J Coast Conserv 15(1):37-50

Bajabaa S, Masoud M et al (2014) Flash flood hazard mapping based on quantitative hydrology, geomorphology and GIS techniques (case study of Wadi Al Lith, Saudi Arabia). Arab J Geosci 7(6):2469-2481

BBC (2009) Flood deaths in Saudi Arabia rise to around 100. BBC

Becker D, Sultan M et al (2012) Integrated solutions for hydrologic investigations in arid lands. Geosphere 8(6):1588-1605

Beven KJ (2011) Rainfall-runoff modelling: the primer. Wiley, Chichester, West Sussex, United Kingdom

Bird S, Hogan D et al (2010) Photogrammetric monitoring of small streams under a riparian forest canopy. Earth Surf Proc Land 35(8):952-970

Brasington J, Smart R (2003) Close range digital photogrammetric analysis of experimental drainage basin evolution. Earth Surf Proc Land J Br Geomorphol Res Group 28(3):231-247

Camarasa-Belmonte AM (2016) Flash floods in Mediterranean ephemeral streams in Valencia Region (Spain). J Hydrol 541:99-115

Chennu S, Grésillon J et al (2007) Efficiency of distributed flood mitigation measures at watershed scale. In: WaReLa scientific conference on integrated catchment management for hazard mitigation, Trier, Germany

Cools J, Vanderkimpen P et al (2012) An early warning system for flash floods in hyper-arid Egypt. Nat Hazards Earth Syst Sci 12(2):443-457

Dawod GM, Mirza MN et al (2011) GIS-based spatial mapping of flash flood hazard in Makkah city, Saudi Arabia. J Geogr Inf Syst 3(03):225 
Dawod GM, Mirza MN et al (2012) GIS-based estimation of flood hazard impacts on road network in Makkah city, Saudi Arabia. Environ Earth Sci 67(8):2205-2215

Dawson RJ, Ball T et al (2011) Assessing the effectiveness of non-structural flood management measures in the Thames Estuary under conditions of socio-economic and environmental change. Glob Environ Change 21(2):628-646

De Vries AJ, Ouwersloot HG et al (2018) Identification of tropical-extratropical interactions and extreme precipitation events in the Middle East based on potential vorticity and moisture transport. J Geophys Res Atmos 123(2):861-881

Del Giudice G, Rasulo G et al (2014) Combined effects of parallel and series detention basins for flood peak reduction. Water Resour Manage 28(10):3193-3205

Detert M, Weitbrecht V (2015) A low-cost airborne velocimetry system: proof of concept. J Hydraul Res 53(4):532-539

Ebert A, Kerle N et al (2009) Urban social vulnerability assessment with physical proxies and spatial metrics derived from air-and spaceborne imagery and GIS data. Nat Hazards 48(2):275294

El-Behiry M, Shedid A et al (2006) Integrated GIS and remote sensing for runoff hazard analysis in Ain Sukhna Industrial area, Egypt. Earth Sci 17(1)

El-Magd IA, Hermas E et al (2010) GIS-modelling of the spatial variability of flash flood hazard in Abu Dabbab catchment, Red sea region, Egypt. J Remote Sens Space Sci 13(1):81-88

El Bastawesy M, White K et al (2009) Integration of remote sensing and GIS for modelling flash floods in Wadi Hudain catchment, Egypt. Hydrol Process 23(9):1359-1368

El Shamy IZ (1992) Recent recharge and flash flooding opportunities in the Eastern Desert, Egypt

Elewa HH, Qaddah AA (2011) Groundwater potentiality mapping in the Sinai Peninsula, Egypt, using remote sensing and GIS-watershed-based modeling. Hydrogeol J 19(3):613-628

Elewa H, Qaddah A et al (2012) Determining potential sites for runoff water harvesting using remote sensing and geographic information systems-based modeling in Sinai. Am J Environ Sci 8(1):42-55

Elewa HH, Ramadan EM et al (2013) Runoff water harvesting optimization by using RS, GIS and Watershed modelling in Wadi El-Arish, Sinai. Int J Eng Res Technol 2(12):1635-1648

Elkhrachy I (2015) Flash flood hazard mapping using satellite images and GIS tools: a case study of Najran city, Kingdom of Saudi Arabia (KSA). Egypt J Remote Sens Space Sci 18(2):261278

Emerson CH, Welty $\mathrm{C}$ et al (2005) Watershed-scale evaluation of a system of storm water detention basins. J Hydrol Eng 10(3):237-242

Fathy I et al (2015) Runoff hydrograph modeling for arid regions: case study—Wadi Sudr-Sinai. Int Water Technol J IWTJ 5:58-68

Foody GM, Ghoneim EM et al (2004) Predicting locations sensitive to flash flooding in an arid environment. J Hydrol 292(1-4):48-58

Ghoneim E, Foody GM (2013) Assessing flash flood hazard in an arid mountainous region. Arab J Geosci 6(4):1191-1202

Guardian T (2018) Jordan: flash floods kill 12 and force tourists to flee. The Guardian

Guha-Sapir D, Below R et al (2016) EM-DAT: the CRED/OFDA international disaster database

Hadadin N et al (2013) Hydrological analysis for floodplain hazard of Jeddah's drainage Basin, Saudi Arabia. Arab J Sci Eng 38(12):3275-3287

Hall JW, Penning-Rowsell EC (2011) Setting the scene for flood risk management. Flood Risk Sci Manage 1-16

Hansson K, Danielson M et al (2008) A framework for evaluation of flood management strategies. J Environ Manage 86(3):465-480

HEC (1998) Flood damage reduction analysis: HEC-FDA user's manual, vol 72. Davis, CA

Heidari A (2009) Structural master plan of flood mitigation measures. Nat Hazards Earth Syst Sci 9 (1):61-75 
Ho M, Lall U et al (2017) The future role of dams in the United States of America. Water Resour Res 53(2):982-998

Hungr O, Morgan G et al (1987) Debris flow defenses in British Columbia. Debris Flows/ Avalanches Process Recogn Mitig. Geol Soc Am Rev Eng Geol 7:201-222

Ibrahim SM, Masoud MH et al (2011) Hydrology of Wadi Abadi-Eastern Desert-Egypt. Assiut Univ J Geol 40(2):1-31

IFRC (2013) Sudan: floods emergency appeal $n^{\circ}$ MDRSD018, IFRC (Published in 13 August 2013)

Ismail YL, Othman AA et al (2010) Impact of flash flood on development potentials of Wadi Abu Ghusun, Eastern Desert, Egypt. Kuwait J Sci Eng 37(2 A):111-134

Jackson JA, Bates R (1997) Glossary of geology: Alexandria. Va Am Geol Inst 769

Jonkman SN, van Gelder P et al (2003) An overview of quantitative risk measures for loss of life and economic damage. J Hazard Mater 99(1):1-30

Kantoush SA, Sumi T et al (2011) JE-HydroNet: modern methodologies for the management, monitoring and planning of integrated water resources in the Nile delta of Egypt. In: 34th IAHRWorld congress, 33rd hydrology and water resources symposium and 10th conference on hydraulics in water engineering, Australia

Kehew AE, Milewski A et al (2010) Reconstructing an extreme flood from boulder transport and rainfall-runoff modelling: Wadi Isla, South Sinai, Egypt. Glob Planet Change 70(1-4):64-75

Kilpatrick FA, Cobb ED (1985) Measurement of discharge using tracers, Department of the Interior, US Geological Survey

Knighton A, Nanson G (1997) Distinctiveness, diversity and uniqueness in arid zone river systems. In: Thomas DSG (ed) Arid zone geomorphology: process, form and change in drylands, 2nd edn. Wiley, pp 185-203

Kundzewicz ZW (2002) Non-structural flood protection and sustainability. Water Int 27(1):3-13

Kundzewicz ZW, Kaczmarek Z (2000) Coping with hydrological extremes. Water Int 25(1):66-75

Kurz B, Wang X et al (2007) An evaluation of basinwide, distributed storage in the Red river basin: the Waffle ${ }^{\circledR}$ concept, vol 23. Energy \& Environmental Research Center, University of North Dakota. Accessed Nov 2011

Lange J, Leibundgut C et al (1999) A noncalibrated rainfall-runoff model for large, arid catchments. Water Resour Res 35(7):2161-2172

Lange J, Liebundgut $\mathrm{C}$ et al (2000) The importance of single events in arid zone rainfall-runoff modelling. Phys Chem Earth Part B Hydrol Oceans Atmos 25(7-8):673-677

Laure Van Ruymbeke (2018) APN news. https://apnews.com/article/ db926fe441be475cb653ab1cfe7ee199

Leblois E, Poulard C et al (2010) Design of dry dams at watershed scale: lessons learnt from sensitivity analyses using a simple but consistent rainfall-runoff model. Balwois, Ohrid, France

Lin X (1999) Flash floods in arid and semi-arid zones. Technical documents in hydrology, UNESCO

Masoud M (2013) The possible impact of the prevailing physiographic features of selected catchments upon their hydrological characteristics, Egypt (comparative study). Aust J Basic Appl Sci 7(14):324-347

McBain W (2012) Twenty-first century flood risk management. Flood risk: planning, design and management of flood defence infrastructure. ICE Publishing, pp 7-22

McIntyre N, Al-Qurashi A (2009) Performance of ten rainfall-runoff models applied to an arid catchment in Oman. Environ Model Softw 24(6):726-738

McLane J, Wüst R (2000) Flood hazards and protection measures in the Valley of the Kings. CRM-WASHINGTON 23(6):35-38

Merz B, Thieken AH (2004) Flood risk analysis: concepts and challenges. Österr Wasser Abfallwirtsch 56(3-4):27-34

Merz B, Kreibich H et al (2008) Flood risk analysis: uncertainties and validation. Österr Wasser Abfallwirtsch 60(5-6):89-94 
Merz B, Hall J et al (2010) Fluvial flood risk management in a changing world. Nat Hazards Earth Syst Sci 10(3):509-527

Milewski A, Sultan M et al (2009) A remote sensing solution for estimating runoff and recharge in arid environments. J Hydrol 373(1-2):1-14

Moneim AA (2005) Overview of the geomorphological and hydrogeological characteristics of the Eastern desert of Egypt. Hydrogeol J 13(2):416-425

Montaldo N, Mancini M et al (2004) Flood hydrograph attenuation induced by a reservoir system: analysis with a distributed rainfall-runoff model. Hydrol Process 18(3):545-563

Mostafazadeh R, Sadoddin A et al (2017) Scenario analysis of flood control structures using a multi-criteria decision-making technique in Northeast Iran. Nat Hazards 87(3):1827-1846

MRMWR (2015) Oman, Ministry of Regional Municipalities and Water Resources

Murata M, Ozawa H et al (2015) Post Aswan High Dam flash floods in Egypt: causes, consequences and mitigation strategies. Bull Cent Collab Community Naruto Univ Educ 29:173-186

Newman L (2005) Uncertainty, innovation, and dynamic sustainable development. Sustain Sci Pract Policy 1(2)

Omran A, Schroder D et al (2011) Flood hazard assessment in Wadi Dahab, Egypt based on basin morphometry using GIS techniques. GI_Forum Program Committee

Onusluel Gul G, Harmancioglu N et al (2010) A combined hydrologic and hydraulic modeling approach for testing efficiency of structural flood control measures. Nat Hazards 54(2):245-260

Perks MT, Russell AJ, Large ARG (2016) Technical note: advances in flash flood monitoring using unmanned aerial vehicles (UAVs). Hydrol Earth Syst Sci 20:4005-4015

Pilgrim D, Chapman T et al (1988) Problems of rainfall-runoff modelling in arid and semiarid regions. Hydrol Sci J 33(4):379-400

Plate EJ (2002) Flood risk and flood management. J Hydrol 267(1-2):2-11

Ramireddygari S, Sophocleous MA et al (2000) Development and application of a comprehensive simulation model to evaluate impacts of watershed structures and irrigation water use on streamflow and groundwater: the case of Wet Walnut Creek Watershed, Kansas, USA. J Hydrol 236(3-4):223-246

Ravazzani G, Gianoli P et al (2014) Assessing downstream impacts of detention basins in urbanized river basins using a distributed hydrological model. Water Resour Manage 28 (4): $1033-1044$

Richards J, White I et al (2008) Local planning practice and flood risk management in England: is there a collective implementation deficit? Environnement Urbain/Urban Environ 2:11-20

Rodier J, Roche M (1978) River flow in arid regions. Hydrom Prin Pract 453

Saber M (2010) Hydrological approaches of Wadi system considering flash floods in arid regions. Kyoto, Graduate School of Engineering, Kyoto University

Saber M, Habib E (2015) Flash floods modelling for wadi system: challenges and trends. Landscape Dyn Soils Hydrol Process Varied Climates 317-339

Saber M, Hamaguchi T et al (2010a) Flash flooding simulation using hydrological modeling of Wadi basins at Nile river based on satellite remote sensing data

Saber M, Hamagutchi T et al (2010b) Hydrological modeling of distributed runoff throughout comparative study between some Arabian wadi basins. Annu J Hydraul Eng Jpn Soc Civil Eng 54:85-90

Saber M, Hamaguchi T et al (2015) A physically based distributed hydrological model of wadi system to simulate flash floods in arid regions. Arab J Geosci 8(1):143-160

Saber M, Kantoush S et al (2017a) Assessing flash floods prone regions at wadi basins in Aswan, Egypt. 京都大学防災研究所年報. B= Disaster Prev Res Inst Annuals B 60(B):853-863

Saber M, Kantoush S et al (2017b) Assessing flash floods prone regions at Wadi basins in Aswan, Egypt. Annu Disaster Prev Res Inst 60 B:427-437 
Saber M, Kantoush SA et al (2020) Assessment of spatiotemporal variability of water storage in Arabian countries using global datasets: implications for water resources management. Urban Water J 1-15

Sayers P, Yuanyuan L et al (2013) Flood risk management: a strategic approach. Asian Development Bank, GIWP, UNESCO and WWF-UK

Scoones I, Leach M et al (2007) Dynamic systems and the challenge of sustainability

Sen Z (2008) Wadi hydrology. CRC Press, New York

Sen Z, Khiyami HA et al (2013) Flash flood inundation map preparation for wadis in arid regions. Arab J Geosci 6(9):3563-3572

Shadeed S, Almasri M (2010) Application of GIS-based SCS-CN method in West Bank catchments, Palestine. Water Sci Eng 3(1):1-13

Shah AA (2015) Assessing the influence of watershed characteristics on the flood vulnerability of Jhelum Basin in Kashmir Himalaya by Gowhar et al., 2015. Nat Hazards 77(3):2139-2143

Shah MAR, Rahman A et al (2015) Challenges for achieving sustainable flood risk management. J Flood Risk Manage 7

Sherif MM, Mohamed MM et al (2010) Rainfall runoff modeling of three Wadis in the Northern area of UAE. J Hydrol Eng 16(1):10-20

Shi Q (2014) Flood hazard assessment along the Western regions of Saudi Arabia using GIS-based morphometry and remote sensing techniques

Soussa H et al (2012) Flood hazard in wadi Rahbaa area, Egypt. Arab J Geosci 5(1):45-52

Stedinger JR (1993) Frequency analysis of extreme events. In: Handbook of hydrology, vol 18

Sultan M, Metwally S et al (2011) Modern recharge to fossil aquifers: geochemical, geophysical, and modeling constraints. J Hydrol 403(1):14-24

Sumi T, Saber M et al (2013) Japan-Egypt hydro network: science and technology collaborative research for flash flood management. J Disaster Res 8(1):28-36

Tapsell SM, Penning-Rowsell EC et al (2002) Vulnerability to flooding: health and social dimensions. Philos Trans Royal Soc Lond A Math Phys Eng Sci 360(1796):1511-1525

Tauro F, Porfiri M et al (2016) Surface flow measurements from drones. J Hydrol 540:240-245

Thomas NW (2015) Simulating the hydrologic impact of distributed flood mitigation practices, tile drainage, and terraces in an agricultural catchment. Ph.D, Graduate College, Iowa, The University of Iowa

Tomsett C, Leyland J (2019) Remote sensing of river corridors: a review of current trends and future directions. River Res Appl 35(7):779-803

Viglione A, Rogger M (2014) Flood processes and hazards. Hydro Meteorol Hazards Risks Disasters 3-33

Wheater HS, Butler AP et al (1991) A multivariate spatial-temporal model of rainfall in southwest Saudi Arabia. I. Spatial rainfall characteristics and model formulation. J Hydrol 125(3-4):175199

Wheater H, Sorooshian S et al (2007) Hydrological modelling in arid and semi-arid areas. Cambridge University Press

White I, Richards J (2007) Planning policy and flood risk: the translation of national guidance into local policy. Plan Pract Res 22(4):513-534

Wu S-J, Yang J-C et al (2011) Risk analysis for flood-control structure under consideration of uncertainties in design flood. Nat Hazards 58(1):117-140

Youssef A, Hegab M (2005) Using geographic information systems and statistics for developing a database management system of the flood hazard for Ras Gharib area, Eastern Desert, Egypt. In: The fourth international conference on the geology of Africa 
Youssef AM, Maerz NH (2013) Overview of some geological hazards in the Saudi Arabia. Environ Earth Sci 70(7):3115-3130

Youssef AM, Pradhan B et al (2009) Geomorphological hazard analysis along the Egyptian Red Sea coast between Safaga and Quseir. Nat Hazards Earth Syst Sci 9(3):751-766

Youssef AM, Pradhan B et al (2015) Use of geological and geomorphological parameters in potential suitability assessment for urban planning development at Wadi Al-Asla basin, Jeddah, Kingdom of Saudi Arabia. Arab J Geosci 8(8):5617-5630

Youssef AM, Pradhan B, Hassan AM (2011) Flash flood risk estimation along the St. Katherine road, southern Sinai, Egypt using GIS based morphometry and satellite imagery. Environ Earth Sci 62(3):611-623

Open Access This chapter is licensed under the terms of the Creative Commons Attribution 4.0 International License (http://creativecommons.org/licenses/by/4.0/), which permits use, sharing, adaptation, distribution and reproduction in any medium or format, as long as you give appropriate credit to the original author(s) and the source, provide a link to the Creative Commons license and indicate if changes were made.

The images or other third party material in this chapter are included in the chapter's Creative Commons license, unless indicated otherwise in a credit line to the material. If material is not included in the chapter's Creative Commons license and your intended use is not permitted by statutory regulation or exceeds the permitted use, you will need to obtain permission directly from the copyright holder. 